\title{
Phenotype Heterogeneity in Glucokinase-Maturity-Onset Diabetes of the Young (GCK-MODY) Patients
}

\author{
Anna Wędrychowicz ${ }^{1 *}$, Ewa Tobór ${ }^{2 *}$, Magdalena Wilk ${ }^{2 *}$, Ewa Ziółkowska-Ledwith², Anna Rams ${ }^{2}$, Katarzyna Wzorek², \\ Barbara Sabal', Małgorzata Stelmach ${ }^{1}$, Jerzy B. Starzyk ${ }^{1}$ \\ ${ }^{1}$ Polish-American Pediatric Institute, Jagiellonian University Collegium Medicum, Department of Pediatric and Adolescent Endocrinology, Cracow, \\ Poland \\ ${ }^{2}$ Polish-American Pediatric Institute, Jagiellonian University Collegium Medicum, Students' Scientific Group at the Department of Pediatric and \\ Adolescent Endocrinology, Cracow, Poland \\ *Equal main/first authors
}

\begin{abstract}
What is already known on this topic?
Monogenic glucokinase-maturity-onset diabetes of the young (GCK-MODY) is the second most common type of diabetes mellitus (DM) after type $1 \mathrm{DM}$ in a population of children and adolescents in Central Europe. Since it has been possible to genetically test patients with DM, the number of CGK-MODY patients in Poland has been increasing.
\end{abstract}

\section{What this study adds?}

This paper presents the detailed clinical presentation of GCK-MODY patients. Only $32 \%$ of all analyzed GCK-MODY carriers fulfilled DM diagnostic criteria, the rest presented with impaired fasting glucose or glucose intolerance. Our clinical data could help to identify GCKMODY patients among patients with DM. The proper diagnosis could avoid insulin therapy in young patients which had previously been misdiagnosed as type 1 DM.

\footnotetext{
Abstract

Objective: The aim of the study was to evaluate the clinical phenotypes of glucokinase-maturity-onset diabetes of the young (GCKMODY) pediatric patients from Southwest Poland and to search for phenotype-genotype correlations.

Methods: We conducted a retrospective analysis of data on 37 CGK-MODY patients consisting of 21 girls and 16 boys of ages $1.9-20.1$ (mean 12.5 \pm 5.2 ) years, treated in our centre in the time period between 2002 and 2013.

Results: GCK-MODY carriers were found in a frequency of $3 \%$ among 1043 diabetes mellitus (DM) patients and constituted the second most numerous group of DM patients, following type $1 \mathrm{DM}$, in our centre. The mean age of GCK-MODY diagnosis was $10.4 \pm 4.5$ years. The findings leading to the diagnosis were impaired fasting glucose (IFG) (15/37), symptoms of hyperglycemia (4/37), and a GCK-MODY family history (18/37). Mean fasting blood glucose level was $6.67 \pm 1.64 \mathrm{mmol} / \mathrm{L}$. In the sample, there were patients with normal values (4/37), those with DM (10/37), and IFG (23/37). In OGTT, 120 min glucose level was normal in 8, diabetic in 2, and characteristic for glucose intolerance in 27 of the 37 cases. Twelve of the 37 cases (32\%) were identified as GCK-MODY carriers. In the total group, mean C-peptide level was $2.13 \pm 0.65 \mathrm{ng} / \mathrm{mL}$ and HbA1c was $6.26 \pm 0.45 \%$ (44.9 $\pm-18 \mathrm{mmol} / \mathrm{mol})$. Thirty-two patients had a family history of DM. DM autoantibodies were detected in two patients. The most common mutations were p.Gly318Arg (11/37) and p.Val302Leu (8/37). There was no correlation between type of mutations and plasma glucose levels.

Conclusion: The phenotype of GCK-MODY patients may vary from those characteristic for other DM types to an asymptomatic state with normal FG with no correlation with genotype.

Keywords: Glucokinase-Maturity-Onset Diabetes of the Young, GCK-MODY, children, adolescents, genotype, phenotype

Address for Correspondence: Anna Wedrychowicz MD, Polish-American Pediatric Institute, Jagiellonian University Collegium Medicum, Department of Pediatric and Adolescent Endocrinology, Cracow, Poland Phone: +48 126581277 E-mail: anna.wedrychowicz@uj.edu.pl ORCID ID: orcid.org/0000-0003-0864-6810 This study was presented in: A. Rams, M. Wilk, E. Ziótkowska, E. Tobór, A. Wedrychowicz, J. Starzyk: Clinical characteristic of Maturity-onset diabetes of the young (MODY) type 2 in children and adolescents. International Medical Students' Conference. Kraków, 12.04.2012. A. Wedrychowicz, M. Stelmach, M. Ciechanowska, J. Nazim, J. Starzyk: Clinical presentation of Maturity-onset diabetes of the young (MODY) 2 in children and adolescents-single centre observations. $5 t^{\text {th }}$ Annual Meeting of the European Society for Pediatric Endocrinology (ESPE), Leipzig, Germany, 20-23.09.2012.

${ }^{\circ}$ Copyright 2017 by Turkish Pediatric Endocrinology and Diabetes Society

The Journal of Clinical Research in Pediatric Endocrinology published by Galenos Publishing House.

Conflict of interest: None declared Received: 07.03.2017 Accepted: 24.06 .2017
} 


\section{Introduction}

Maturity-onset diabetes of the young (MODY) is a monogenic form of diabetes inherited in an autosomal dominant way $(1,2)$. There are over 800 known mutations associated with MODY and new ones are being discovered all the time (3). Glucokinase-maturity-onset diabetes of the young (GCKMODY), also known as MODY type 2 , is the most common type of the monogenic diabetes in Poland (4), and, along with a HNF1A- MODY, is one of the most common in the world. It is caused by a heterozygous mutation in the glucokinase gene on chromosome 7 (5). Glucokinase in the pancreatic beta cells senses increased blood glucose levels and controls the release of insulin. The heterozygous mutation in the glucokinase-coding gene results in a changed insulin threshold and therefore persistent hyperglycemia (6). As the hyperglycemia is mild and does not progress or cause any long-term complications, it may remain unnoticed (7).

GCK-MODY patients are usually non-obese, do not require treatment, and do not have vascular complications. This is the reason why it is important to differentiate this type from diabetes mellitus type 1 and type 2 (DM1 and DM2) in order to avoid unnecessary treatment $(3,8,9,10)$. It should also be kept in mind that at the beginning, MODY was considered as a rare form of diabetes, however, it is probably much more common than assumed but often remains undiagnosed. By spreading knowledge of the existence of groups of diabetes such as MODY, and through the possibility of molecular testing, we should be able to change this situation.

The aim of this present study was to evaluate the clinical phenotype of GCK-MODY patients from Southwestern Poland treated in our department and also to search for phenotype-genotype correlations.

\section{Methods}

For this retrospective analysis, of all 1043 patients with DM treated in the Department of Pediatric and Adolescent Endocrinology in Cracow, we selected 37 (21 girls and 16 boys) aged between 1.92 and 20.1 years, with a mean age of $12.5 \pm 5.2$ years, and with genetically confirmed GCKMODY, which were included in the study. All participants and/or their parents gave their written informed consent to use their clinical data in scientific publications. All patients had been treated in our department in the years 2002-2013.

The following data were analyzed in details: age at GCKMODY diagnosis, anthropometric data at diagnosis and during treatment, signs and symptoms at the time of diagnosis, medical history including course of pregnancy, birth parameters, and family history. Results of oral glucose tolerance test (OGTT), C-peptide, HbA1c, lipid profile, autoantibodies, and presence of other co-morbidities were also analyzed.

The clinical molecular testing was performed in an approved laboratory, with results interpreted by a board-certified clinical molecular geneticist or molecular genetic pathologist or the equivalent, in accordance with the American College of Medical Genetics (ACMG) Standards and Guidelines 2015 (11). The gene mutations were assessed in the Laboratory of Immunopathology and Genetics, Medical University of Lodz, Poland, which has achieved the International Quality Certificate ISO 9001:2008, a certificate of the Polish Society of Human Genetics. Molecular testing was performed by DNA sequencing performed using fluorescent-labeled terminating deoxynucleoside triphosphates with genespecific oligonucleotide primers and multiplex ligationdependent probe amplification to detect ezon deletions (MRC-Holland, Amsterdam, The Netherlands). Details of the molecular methods used in our patients were reported previously $(4,12)$. The molecular testing was also performed in family members of patients including parents, siblings, and grandparents with impaired fasting glucose (IFG), glucose intolerance (GI), or DM.

Anthropometric measurements were taken in all patients. Height was measured to the nearest millimeter using a rigid stadiometer. Weight was measured to the nearest $0.1 \mathrm{~kg}$ using a calibrated balance scale. Reference data for Polish children were used for assessment (13). Body mass index (BMI) was calculated as weight in kilograms (kg) divided by the square of the height in meters $\left(\mathrm{m}^{2}\right)$.

The statistical analysis was performed using Statistica/ MS Exel programs. Student's t-test was used to compare the analyzed groups. A p-value $<0.05$ was considered as statistically significant.

\section{Results}

GCK-MODY carriers amounted for $3 \%$ of all DM patients in our center (37/1043). The mean age at diagnosis was $10.4 \pm 4.5$ years. The suspicion of GCK-MODY was based on different heterogeneous signs, symptoms, and results of laboratory tests. 14/37 patients presented with an IFG, 4/37 patients were admitted with symptoms of hyperglycemia (polydipsia, polyuria, fatigue), 1 patient was obese and presented with IFG, and 18/37 patients had had monogenic DM previously diagnosed in their family. Before the confirmation of GCK mutation, 9/37 patients were treated as DM1 and in 6/37 cases insulin had been administered.

The mean serum fasting glucose level was $6.67 \pm 1.64$ $\mathrm{mmol} / \mathrm{L}$ and the level ranged between 5.2 and $9.2 \mathrm{mmol} / \mathrm{L}$. 
According to their blood glucose levels, the patients could be divided into three groups: those (4/34 patients) with normal values with a glucose level below $5.5 \mathrm{mmol} / \mathrm{L}$ (100 $\mathrm{mg} / \mathrm{dL}$ ), those (10/34 patients) with a glucose level above $6.9 \mathrm{mmol} / \mathrm{L}(125 \mathrm{mg} / \mathrm{dL})$ characteristic for $\mathrm{DM}$, and the remaining group (20/34) with an IFG 5.5-6.9 mmol/L (100$125 \mathrm{mg} / \mathrm{dL}$ ). The profiles for OGTT results were also variable. The 120 min glucose level was normal in $8 / 26$ patients and lower than $7.8 \mathrm{mmol} / \mathrm{L}$ (140 $\mathrm{mg} / \mathrm{dL}$ ). Two of the 26 patients had a result characteristic for DM, namely, higher than 11.1 $\mathrm{mmol} / \mathrm{L}(200 \mathrm{mg} / \mathrm{dL})$, and the remaining patients $(16 / 26)$ had GI with values between 6.9 and $11.1 \mathrm{mmol} / \mathrm{L}(140-200$ $\mathrm{mg} / \mathrm{dL}$ ). Thus, 12 of the 37 patients $(32 \%)$ who were CGKMODY carriers fulfilled the criteria of DM according to the Polish Diabetes Association recommendations (14). This figure is equivalent to $12 / 1043(1.15 \%)$ of all patients with DM in our center.

The mean fasting C-peptide level was $2.13 \pm 0.65 \mathrm{ng} /$ $\mathrm{mL}$ (normal ranges $0.2-4.2 \mathrm{ng} / \mathrm{mL}$ ) and in $18 / 19$ cases the result was above $0.75 \mathrm{ng} / \mathrm{mL}$. Mean $\mathrm{HbA} 1 \mathrm{c}$ level at diagnosis was $6.26 \pm 0.45 \%(44.9 \mathrm{mmol} / \mathrm{mol})$. This changed during the diet alone treatment into $6.13 \pm 0.39$ $\%(43.5 \mathrm{mmol} / \mathrm{mol})$ and the difference between the results was statistically significant $(p<0.013)$. Six patients (6/37) had an elevated LDL cholesterol and five patients $(5 / 37)$ had elevated total cholesterol levels. The mean levels of total cholesterol $(4.58 \pm 1.02 \mathrm{mmol} / \mathrm{L})$, LDL cholesterol $(2.52 \pm 1.02 \mathrm{mmol} / \mathrm{L})$, high-density lipoprotein (HDL) cholesterol $(1.4 \pm 0.23 \mathrm{mmol} / \mathrm{L})$, and triglycerides $(0.99 \pm 0.35 \mathrm{mmol} / \mathrm{L})$ were within normal ranges.

One patient was obese and one was underweight, the rest had BMI results normal for age. Two children (siblings) were diagnosed because of short stature and in both cases, pathological causes of short stature were excluded. Height of the other children were within normal ranges for age and compatible with their mid-parental height values.

Eighteen of the mothers of these children (18/37) had a confirmed GCK mutation, usually during family genetic tests. Two mothers $(2 / 37)$ are being treated for DM2. Six mothers (6/37) were diagnosed with diabetes during pregnancy, found through routine screening, and all of them are GCK mutation carriers. In two of their children (2/37), birth weights were greater or equal to $4000 \mathrm{~g}$. In both of these cases, children had the same GCK mutations as their mothers. Three patients (3/37) were small for gestational age babies (15). All these patients got their mutations from their fathers. Two of them were twins.

The patients presented highly incriminating family histories. In the case of 32 patients (32/37) one of the parents (18 mothers, 12 fathers) was diagnosed with diabetes GCKMODY and had the same mutation as her/his child. A clear autosomal dominant mode of inheritance was presented. In five cases (5/37), the histories are not known. In an interview with 21 patients (21/37), diabetes also appears in one of the grandparents. The great-grandparents of 4 patients (4/37) had a confirmed GCK mutation.

Autoantibodies typical for DM1 such as islet cell autoantibodies (ICA), insulin autoantibodies, glutamic acid decarboxylase (GAD) autoantibodies, tyrosine kinase autoantibodies, were detected in 2 patients (2/37). One of these two patients had all four above-mentioned antibodies positive, while only ICA autoantibodies were positive in the second patient. Autoimmune diseases were not observed in this group of patients. Three patients (3/37) had Gilbert disease.

Thirteen mutations of the GCK gene were identified. Eleven (11) of these were missense mutations, one nonsense mutation, and one deletion (Table 1). The most common were p.Gly318Arg (11/36) and p.Val302Leu (8/36). Seven subjects with the second mutation (7/8) are members of the same family.

The variability of glucose levels was also observed within the carriers of the same mutation (p.Gly318Arg, p.Val302Leu).

Regarding the OGTT profile, we observed two different patterns in p.Gly318Arg mutation carriers. In 3 of these 11 patients, the mean increase in plasma glucose level was 5.56 $\mathrm{mmol} / \mathrm{L}$ and the $120 \mathrm{~min}$ result was typical for DM, whereas

Table 1. Types of glucokinase mutations in our patients

\begin{tabular}{ll}
\hline Type of mutation/Protein effect & Number of patients \\
\hline G > A p.(Gly318Arg) & 11 \\
G > C p.(Val302Leu) & 8 \\
C > T p.(Ser383Leu) & 4 \\
G > A p.(Gly44Asp) & 3 \\
delCTT p.(Ser212del) & 2 \\
C > A p.(Arg377Gln) & 1 \\
A > T p.(Asp198Val) & 1 \\
G > A p.(Gly176Arg) & 1 \\
G > T p.(Glu157Ter) & 1 \\
G > A p.(Val226Met) & 1 \\
G > A p.(Glu221 Lys) & 1 \\
C > A p.(Arg37Gln) & 1 \\
T > C p.(Ser212Pro) & 1 \\
\hline
\end{tabular}


in two other subjects $(2 / 11)$, the mean increase was 1.45 $\mathrm{mmol} / \mathrm{L}$ and at $120 \mathrm{~min}$, the glucose level was within the normal range. At baseline, the glucose level was increased but similar in both groups (5.2-6.7 mmol/L) (Table 2).

A similar situation was observed in the carriers of p.Val302Leu mutation. Baseline glucose levels were elevated in all patients in this group, ranging from $5.5 \mathrm{mmol} / \mathrm{L}$ to $6.23 \mathrm{mmol} / \mathrm{L}$ (Table 3). Three patients (3/8) had a mean increase of $0.5 \mathrm{mmol} / \mathrm{L}$ in OGTT at $120 \mathrm{~min}$ and normal glucose levels, while two others (2/8) showed an increase of $2.95 \mathrm{mmol} / \mathrm{L}$ and the glucose levels suggest GI. Presented differences had no relationship with the age of the patients.

\section{Discussion}

GCK-MODY is mostly described as an asymptomatic condition, with mild fasting hyperglycemia (5.5-8 mmol/L), minor postprandial glucose extrusion, and a family history of diabetes. Usually, only a proper diet is sufficient to

Table 2. Oral glucose tolerance test profile in p.Gly318Arg mutation carriers

\begin{tabular}{llll}
\hline $\begin{array}{l}\text { Patients with } \\
\text { p.Gly318Arg } \\
\text { mutation }\end{array}$ & $\begin{array}{l}\text { Blood } \\
\text { glucose } \\
(\mathbf{m m o l} / \mathrm{L}) \\
\mathbf{0} \mathbf{~ m i n}\end{array}$ & $\begin{array}{l}\text { Blood } \\
\text { glucose } \\
(\mathbf{m m o l} / \mathrm{L}) \\
\mathbf{1 2 0} \mathbf{~ m i n}\end{array}$ & $\begin{array}{l}\text { Increase of } \\
\text { blood glucose } \\
\text { in OGTT } \\
(\mathbf{m m o l} / \mathrm{L})\end{array}$ \\
\hline 1 & 6.7 & 12.2 & 5.5 \\
2 & 5.2 & 10.9 & 5.7 \\
3 & 5.8 & 11.3 & 5.5 \\
4 & 6.4 & 7.5 & 1.1 \\
5 & 6 & 7.8 & 1.8 \\
\hline
\end{tabular}

Table 3. Oral glucose tolerance test profile in p.Val302Leu mutation carriers (blood glucose)

\begin{tabular}{llll}
\hline $\begin{array}{l}\text { Patients with } \\
\text { p.Val302Leu } \\
\text { mutation }\end{array}$ & $\begin{array}{l}\text { Blood } \\
\text { glucose } \\
\text { (mmol/L) } \\
\mathbf{0} \text { min }\end{array}$ & $\begin{array}{l}\text { Blood } \\
\text { glucose } \\
\text { (mmol/L) } \\
\mathbf{1 2 0 ~} \mathbf{~ m i n}\end{array}$ & $\begin{array}{l}\text { Increase of } \\
\text { blood glucose } \\
\text { in OGTT } \\
\text { (mmol/L) }\end{array}$ \\
\hline 1 & 5.5 & 9.3 & 3.8 \\
2 & 6.2 & 8.3 & 2.1 \\
3 & 6.2 & 6.7 & 0.5 \\
4 & 5.6 & 6.1 & 0.5 \\
5 & 6.1 & 6.6 & 0.5 \\
\hline
\end{tabular}

maintain an appropriate glucose level and prevent diabetic complications $(1,8,9,10)$. However, new studies have revealed that GCK-MODY patients are not such a homogeneous group and that their phenotypes may vary considerably depending on the type of mutation $(16,17,18)$. Results of these studies indicate that about half of GCK-MODY patients fulfill the criteria of DM, while the rest present with IFG or GI (16). Missense mutations have variable effects on glucokinase activity ranging from a small change in affinity for glucose to complete inactivity (19). Analysis of the clinical data of our patients led to similar conclusions. The mean features of the whole group were similar to those described in the literature, although findings pertaining to characteristics such as autoantibodies, obesity, fasting glucose levels were radically different in some of the patients from those characteristics for other types of diabetes. Compared to previous reports, we observed a lower percentage (32\% vs. $50 \%$ ) of GCK-MODY carriers fulfilling the criteria of DM. OGTT results of patients with two of the most frequent missense mutations (p.Gly318Arg, p.Val302Leu) show that their affinity for glucose does not correlate to the type of the mutation and even within the same mutation, postprandial glucose levels may vary significantly. There is no strong correlation between certain types of mutations and plasma glucose levels, although the threshold of insulin secretion is hypothetically the same. Differences in insulin sensitivity $(20,21)$, diet, and physical activity might be probable reasons for those findings. Potential roles of other genes that modulate GCK function are also possible, considering that the GCKR regulatory protein gene has already been shown to interact with polymorphisms with GCK in a clinically significant way $(22,23)$. GCK mutations affect not only the pancreatic function of this enzyme but the liver function too, where the decrease in the glycogen synthesis and storage, as well as increase in glucogenesis after standard meals, is reported. This defect in hepatic glucose metabolism contributes to postprandial hyperglycemia of GCK-MODY patients $(24,25,26)$.

Our study reports the clinical presentation of 37 patients with confirmed GCK-MODY from a single, pediatric centre in Central Europe. The analysis of the clinical data includes a detailed process of diagnostics and also the assessment of the results of GCK-MODY treatment. The diagnosis of GCK-MODY was suspected on the basis of atypical signs and symptoms of diabetes, or atypical results of treatment, or previous family history of GCK-MODY. The limitation of the study is a lack of genetic tests in the whole group of 1043 patients with DM treated in our department due to financial limitations.

Recent studies report that specific gene mutations can present clinically as a neonatal form as well as type 2- 
like' or 'type 1-like' forms during adulthood (27) which makes diagnosis very difficult especially when symptoms, laboratory tests, and phenotype correspond to 'double' diabetes or even 'triple' diabetes with features of DM1, $\mathrm{DM} 2$, and presence of monogenic mutation. It is not an exception that patients with GCK-MODY are diagnosed as DM1 and treated with insulin. According to the literature, those subjects require higher than replacement doses to improve metabolic control of DM (28) and it may be a reason for their physicians to extend their diagnosis. In our group of patients, two boys presented with such inexplicably high requirement for insulin, whereas in another four children, the requirement for insulin was lower than that of other patients with DM1. These facts together with a strong positive family history of DM should also lead to a suspicion of monogenic diabetes.

Despite wide ranging glucose levels, HbA1c values were similar in all patients and mean levels were below the $10^{\text {th }}$ percentile for diabetic children (22). Furthermore, we observed a significant reduction of HbA1c levels after treatment with diet alone. Reported fasting C-peptide levels above 0.75 , persisting for 3-5 years from diagnosis, are suggestive of DM2 or monogenic diabetes. Similar values are consistent with short-term insulin independence in an individual who has not previously 'failed' non-insulin therapy but may occur in the DM1 diabetes honeymoon period (29).

The prevalence of dyslipidemia encountered in some patients may occur in GCK-MODY but is characteristic rather for DM2 $(19,30)$. The carriers of GCK mutations usually show lower levels of fatty acids and triglycerides in circulation than the healthy population (31). Reduced GCK activity is likely to reduce glycolytic flux and production of both glycogen and malonyl-CoA. The latter is an important regulator of lipid metabolism; reduced levels alleviate inhibition of carnitine palmityl transferase 1 , thereby increasing fatty acid oxidation. In addition, malonyl-CoA is the precursor of fatty acid synthesis; this will potentially also be reduced when GCK activity drops. Moreover, esterification of fatty acids into TAGs would be insufficient owing to reduced production of glycerol-3-phosphate via glycolysis. Thus, overall, hepatic fatty acid and TAG production and glucose metabolism would be decreased in the face of reduced GCK activity (31). Moreover, HDL cholesterol values measured in individuals with likely monogenic diabetes may be useful in screening for GCK-MODY and its differentiation from DM1 and HNF1A-MODY, regardless of treatment or metabolic control (12). The studies performed by Fendler et al (32) showed that individuals with GCK-MODY exhibit a strongly protective profile HDL cholesterol (high concentration of large HDL and low levels of intermediate and small HDL subpopulation). Next to constitutively moderately elevated glycemia observed in these patients, this lipid profile may be also a factor contributing to the low frequency of cardiovascular complications (32).

A twofold increase in incidence of Gilbert disease in our patients compared to the general population appears to be due to inter-family relationships in some of these individuals.

The positive GAD antibodies observed in two patients are not characteristic for GCK-MODY. The prevalence of GAD antibodies and a confirmed genetic diagnosis of MODY may represent the $1-2 \%$ of the population with detectable islet antibodies with no associated pathogenesis. In general, the finding of islet autoantibodies makes the diagnosis of MODY very unlikely, and genetic testing should only be performed if other clinical characteristics strongly suggest this form of diabetes rather than DM1 (33). Furthermore, positive diabetes autoantibodies can be transient in GCKMODY patients and are not markers of prediabetes. It is possible that autoantibody titers are aggravated by obesity or by other factors, such as drugs (34).

Individuals with GCK-MODY are usually not obese and achieve normal growth. The imposition of obesity cannot be excluded, in view of the overall increase in obesity in all populations.

Large population cohort studies of pregnant women estimate the population prevalence of GCK-MODY as 1.1 in 1000 $(35,36)$. The percentage of mutations in females diagnosed with diabetes in pregnancy could be significantly greater. Most importantly, maternal hyperglycemia in pregnancy is the primary risk factor for newborn macrosomia caused by fetal hiperinsulinism. GCK-MODY patients present with good, sometimes even high, insulin production and function but have increased set point stimulated insulin secretion. Usually babies with maternally inherited GCK-MODY and which have an increased set point stimulated insulin secretion, secrete a normal amount of insulin with maternal hyperglycemia, and have normal birth weights. Very high maternal hyperglycemia could result in fetal insulin hypersecretion, and ultimately, an overweight newborn, as was the case in two of our patients. The low birth weight observed in our three patients with paternally inherited GCK-MODY and non-diabetic mothers may be an effect of fetal hyperglycemia due to GCK mutation. Hyperglycemia in these cases is a result of low insulin secretion in the milieu of maternal normoglycemia due to increased set point stimulated insulin secretion.

According to the guidelines for GCK-MODY diagnosis, mild fasting hyperglycemia (5.5-8.0 $\mathrm{mmol} / \mathrm{L})$, small increase in OGTT ( $<4.6 \mathrm{mmol} / \mathrm{L}$ ) at $120 \mathrm{~min}$, negative autoantibodies, 
and MODY diagnosed in one of the parents are key indications for the genetic screening for GCK mutations. Our study shows that the diagnosis of this type of diabetes is more challenging in some cases. The phenotype of GCKMODY patients may vary from one that is characteristic of other types of diabetes to an asymptomatic state with normal fasting glucose levels. Differences in insulin sensitivity, diet, and physical activity may be the probable causes of these findings. Potential roles of other genes modulating GCK function are also possible. The most important observation is that the proper diagnosis of GCK-MODY could lead to cessation of insulin treatment with improvement in the patients' quality of life.

\section{Acknowledgements}

The authors of the article hereby thank Professor Maciej Borowiec and Professor Wojciech Młynarski from the Department of Pediatrics, Oncology, Hematology and Diabetology, Medical University of Lodz, for genetic testing. The authors hereby thank Harry Ledwith for language assistance during the preparation of the manuscript.

\section{Ethics}

Ethics Committee Approval: Retrospective analysis study.

Informed Consent: All participants and/or their parents gave their written informed consent to use their clinical data in scientific publications.

Peer-review: Externally peer-reviewed.

\section{Authorship Contributions}

Concept: Anna Wedrychowicz, Design: Anna Wedrychowicz, Ewa Tobór, Magdalena Wilk, Ewa Ziółkowska-Ledwith, Anna Rams, Katarzyna Wzorek, Barbara Sabal, Data Collection and Processing: Anna Wedrychowicz, Ewa Tobór, Magdalena Wilk, Ewa Ziółkowska-Ledwith, Anna Rams, Katarzyna Wzorek, Barbara Sabal, Małgorzata Stelmach, Analysis and Interpretation: Anna Wedrychowicz, Ewa Tobór, Magdalena Wilk, Ewa Ziółkowska-Ledwith, Anna Rams, Katarzyna Wzorek, Barbara Sabal, Małgorzata Stelmach, Literature Research: Anna Wedrychowicz, Ewa Tobór, Magdalena Wilk, Ewa Ziółkowska-Ledwith, Anna Rams, Katarzyna Wzorek, Barbara Sabal, Małgorzata Stelmach, Writing: Anna Wedrychowicz, Ewa Tobór, Magdalena Wilk, Ewa Ziółkowska-Ledwith, Anna Rams, Jerzy B. Starzyk.

Financial Disclosure: The authors declared that this study received no financial support.

\section{References}

1. Fajans SS, Bell GI. MODY: History, genetics, patophysiology and clinical decision making. Diabetes Care 2011;34:1878-1884.
2. Tattersall RB. Mild familial diabetes with dominant inheritance. Q J Med 1974;:43:339-357

3. Nyunt O, Wu JY, McGown IN, Harris M, Huynh T, Leong GM, Cowley $\mathrm{DM}$, Cotterill AM. Investigating maturity onset diabetes of the young. Clin Biochem Rev 2009;30:67-74.

4. Fendler W, Borowiec M, Antosik K, Baranowska-Jazwiecka A, Szadkowska A, Skala-Zamorowska E, Deja G, Jarosz-Chobot P, Techmańska I, Bautembach-Minkowska J, Myśliwiec M, Zmysłowska A, Pietrzak I, Małecki MT, Młynarski W. Prevalence of monogenic diabetes amongst Polish children after a nationwide genetic screening campaign. Diabetologia 2012;10:2631-2635. Epub 2012 Jul 11

5. Vionnet N, Stoffel M, Takeda J, Yasuda K, Bell GI, Zouali H, Lesage S, Velho G, Iris F, Passa P, Froguel Ph, Cohen D. Nonsense mutation in the glucokinase gene causes early-onset non-insulin-dependent diabetes mellitus. Nature 1992;356:721-722.

6. Byrne MM, Sturis J, Clément K, Vionnet N, Pueryo ME, Stoffel M, Takeda J, Passa P, Cohen D, Bell GI, et al. Insulin secretory abnormalities in subjects with hyperglycemia due to glucokinase mutations. J Clin Invest 1994;93:1120-1130.

7. Velho G, Froguel P, Clement K, Pueyo ME, Rakotoambinina B, Zouali H, Passa P, Cohen D, Robert JJ. Primary pancreatic beta-cell secretory defect caused by mutations in glucokinase gene in kindreds of maturity onset diabetes of the young. Lancet 1992;340:444-448.

8. Velho G, Frogulel P. Genetic, metabolic and clinical characteristic of maturity onset diabetes of a young. Eur J Endocrinol 1998;138:233-239.

9. Vaxillaire M, Froguel P. Genetic basis of maturity-onset diabetes of the young. Endocrinol Metab Clin North Am 2006;35:371-384.

10. Porter JR, Barrett TG. Monogenic syndromes of abnormal glucose homeostasis: clinical review and relevance to the understanding of the pathology of insulin resistance and $\beta$ cell failure. J Med Genet 2005;42:893-902. Epub 2005 Mar 16

11. Richards S, Aziz N, Bale S, Blick D, Das S, Gastier-Foster J, Grody WW, Hegde M, Lyon E, Spector E, Voelkerding K, Rehm HL; ACMG Laboratory Quality Assurance Committee. Standards and guidelines for the interpretation of sequence variants: a joint consensus recommendation of the American College of Medical Genetics and Genomics and the Association for Molecular Pathology. Genet Med 2015;17:405-424. Epub 2015 Mar 5

12. Fendler W, Rizzo M, Borowiec M, Antosik K, Szadkowska A, Deja G, Jarosz-Chobot G, Myśliwiec M, Wyka K, Pietrzak I, Supień J, Małecki MT, Młynarski W. HDL cholesterol as a diagnostic tool for clinical differentiation of GCK-MODY from HNF1 A-MODY and type 1 diabetes in children and young adults. Clin Endocrinol (Oxf) 2011;75:321-327.

13. Palczewska I, Niedźwiecka Z. Siatki centylowe do oceny rozwoju somatycznego dzieci i młodzieży. Instytut Matki i Dziecka, Warszawa, 1999.

14. Polskie Towarzystwo Diabetologiczne. Zalecenia kliniczne dotyczące postępowania u chorych na cukrzycę 2014. Clinical Diabetology 2016;1:3-4.

15. Malewski Z, Słomko Z, Klejewski A. Relacja wieku ciążowego i masy urodzeniowej noworodków z regionu Wielkopolski. I Kongres Polskiego Towarzystwa Medycyny Perinatalnekj. Poznań 1995;2:734-741.

16. Fajans SS, Bell GI. Phenotypic heterogeneity between different mutations of MODY subtypes and within MODY pedigrees. Diabetologia 2006;46:1106-1108. Epub 2006 Feb 25

17. Skupień J, Małecki M. MODY. In: Moczulski D. Wielka internadiabetologia. Medical Tribune Polska, 2010:119-126.

18. Cuesta-Muñoz AL, Tuomi T, Cobo-Vuilleumier N, Koskela H, Odili S, Stride A, Buettger C, Otonkoski T, Froguel P, Grimsby J, Garcia-Gimeno M, Matschinsky FM. Clinical heterogeneity in monogenic diabetes caused by mutations in the glucokinase gene (GCK-MODY). Diabetes Care 2010;33:290-292. Epub 2009 Nov 10 
19. Velho G, Blanché H, Vaxillaire M, Bellanné-Chantelot C, Pardini VC, Timsit J, Passa P, Deschamps I, Robert JJ, Weber IT, Marotta D, Pilkis SJ, Lipkind GM, Bell GI, Froguel P. Identification of 14 new glucokinase mutations and description of the clinical profile of 42 MODY-2 families. Diabetologia 1997;40:217-224.

20. Massa O, Meschi F, Cuesta-Munoz A, Caumo A, Cerutti F, Toni S, Cherubini V, Guazzarotti L, Sulli N, Matschinsky FM, Lorini R, Iafusco D, Barbetti F; Diabetes Study Group of the Italian Society of Paediatic Endocrinology and Diabetes (SIEDP). High prevalence of glucokinase mutations in Italian children with MODY. Influence on glucose tolerance, first-phase insulin response, insulin sensitivity and BMI. Diabetologia 2001;44:898-905.

21. Klupa T, Warram JH, Antonellis A, Pezzolesi M, Nam M, Malecki MT, Doria A, Rich SS, Krolewski AS. Determinants of the development of diabetes (maturity-onset diabetes of the young-3) in carriers of HNF1 alpha mutations: evidence for parent-of-origin effect. Diabetes Care 2002;25:2292-2301.

22. Borowiec M, Antosik K, Fendler W, Deja G, Jarosz-Chobot P, Mysliwiec M, Zmyslowska A, Malecki M, Szadkowska A, Mlynarski W. Novel glucokinase mutations in patients with monogenic diabetes - clinical outline of GCK-MD and potential for founder effect in Slavic population. Clin Genet 2012;813:278-283. Epub 2011 Mar 18

23. Tam CH, Ma RC, So WY, Wang Y, Lam VK, Germer S, Martin M, Chan $\mathrm{JC}, \mathrm{Nq} \mathrm{MC}$. Interaction effect of genetic polymorphisms in glucokinase (GCK) and glucokinase regulatory protein (GCKR) on metabolic traits in healthy chinese adults and adolescents. Diabetes 2009;58:765-769. Epub 2008 Dec 10

24. Tappy L, Dussoix P, Iynedjian P, Henry S, Schneiter P, Zahnd G, Jéquier E, Philippe J. Abnormal regulation of hepatic glucose output in maturity-onset diabetes of the young caused by a specific mutation of the glucokinase gene. Diabetes 1997;46:204-208.

25. Velho G, Petersen KF, Perseghin G, Hwang JH, Rothman DL, Pueyo ME, Cline GW, Froguel P, Shulman GI. Impaired hepatic glycogen synthesis in glucokinase-deficient (MODY-2) subjects. J Clin Invest 1996;98:17551761.

26. Fajans SS, Bell GI, Polonsky KS. Molecular mechanisms and clinical pathophysiology of maturity-onset diabetes of the young. N Engl J Med 2001;345:971-980.
27. Schwitzgebel VM. Many faces of monogenic diabetes. J Diabetes Investig 2014;23:121-133. Epub 2014 Feb 24

28. Gardner DS, Tai ES. Clinical features and treatment of maturity onset diabetes of the young (MODY). Diabetes Metab Syndr Obes 2012;5:101-108.

29. Jones AG, Hattersley AT. The clinical utility of C-peptide measurement in the care of patients with diabetes. Diabet Med 2013;30:803-817.

30. Schober E, Rami B, Grabert M, Thon A, Kapellen T, Reinehr T, Holl RW; DPV-Wiss Initiative of the German Working Group for Paediatric Diabetology and. Phenotypical aspects of maturity-onset diabetes of the young (MODY diabetes) in comparison with Type 2 diabetes mellitus (T2DM) in children and adolescents: experience from a large multicentre database. Diabet Med 2009;26:466-473.

31. Spégel P, Ekholm E, Tuomi T, Groop L, Mulder H, Filipsson K. Metabolite profiling reveals normal metabolic control in carriers of mutations in the glucokinase gene (MODY2). Diabetes 2013;62:653-61. Epub 2012 Nov 8

32. Fendler W, Rizzo M, Borowiec M, Antosik K, Szadkowska A, Deja G, Jarosz-Chobot G, Myśliwiec M, Wyka K, Pietrzak I, Supień J, Małecki MT, Młynarski W. HDL cholesterol as a diagnostic tool for clinical differentiation of GCK-MODY from HNF1 A-MODY and type 1 diabetes in children and young adults. Clin Endocrinol (Oxf) 2011;75:403-404.

33. Fendler W, Rizzo M, Borowiec M, Małachowska B, Antosik K, Szadkowska A, Banach M, Urbańska-Kosińska M, Szopa M, Małecki MT, Młynarski W. Less but better: cardioprotective lipid profile of patients with GCK-MODY despite lower HDL cholesterollevel. Acta Diabetol 2014;51:625-632. Epub 2014 Feb 19

34. McDonald TJ, Colclough K, Brown R, Shields B, Shepherd M, Bingley P, Williams A, Hattersley AT, Ellard S. Islet autoantibodies can discriminate maturity-onset diabetes of the young (MODY) from Type 1 diabetes. Diab Med 2011;28:1028-1033.

35. Wędrychowicz A, Stelmach M, Wyka K, Starzyk J. Like-triple diabetes as first manifestation of MODY2 in an overweight teenager with transient "multiple antibody positive". Diabetes Care 2014;37:66-67.

36. Chakera AJ, Spyer G, Vincent N, Ellard S, Hattersley AT, Dunne FP. The $0.1 \%$ of the population with glucokinase monogenic diabetes can be recognized by clinical characteristics in pregnancy: the Atlantic Diabetes in Pregnancy cohort. Diabetes Care 2014;37:1230-1236. Epub 2014 Feb 18 